INTERNATIONAL HIGHER EDUCATION, Number 70 Winter, 2013

Pages 9-11

\title{
Five Models of International Branch Campus Facility Ownership
}

\author{
JASON E. LANE AND KEVIN KINSER
}

Jason E. Lane is associate professor of educational administration and policy and director of Education Studies at the Rockefeller Institute of Government, and codirector of the Cross-Border Education Research Team at the State University of New York at Albany. E-mail: jlane@albany.edu. Kevin Kinser is associate professor of educational administration and policy, provost's fellow for internationalization collaborations and initiatives, and co-director of the CrossBorder Education Research Team at the State University of New York at Albany. E-mail: kkinser@albany.edu.

IHE dedicates an article in each issue to a contribution from the Cross-Border Education Research Team (C-BERT), headquartered at the State University of New York at Albany. More information about C-BERT can be found at www.globalhighered.org.

Setting up an overseas campus can be a costly endeavor. One reason is the expense associated with building and maintaining a physical infrastructure in another country. In fact, mentioning an international branch campus (IBC) causes many people to think of small replicas of the home campus, set up in a foreign desert or jungle. However, only a handful of campuses are comprised of 
buildings and grounds that would be identifiable as a setting for higher learning. Even when they do have a full campus in the traditional sense, many do not actually own the facilities that they use. For example, the University of Nottingham's campuses in China and Malaysia have replicas of the iconic bell tower located on the UK campus; yet, they do not actually own those buildings.

Our many site visits to IBCs revealed a range of campus types. While some have many buildings, others have only a few rooms. Some are rented; others are fully owned by the home campus. Still others use space provided by partners, which is, however, not owned or rented by the home campus. However, information on this topic has remained largely anecdotal. So, when an international survey of IBCs was conducted, the ownership arrangements of their campus was specifically questioned.

\section{SuRvey Methods ANd IBC Definition}

The survey, conducted in the fall of 2011, was distributed to 180 institutions that met the definition of an entity that is owned, at least in part, by a foreign education provider; operated in the name of the foreign education provider; engages in at least some face-to-face teaching; and provides access to an entire academic program that leads to a credential awarded by the foreign education provider. The only reference to the facilities is that there must be a physical location and space for face-to-face teaching. The mention of ownership in this definition refers to the corporate entity and does not necessarily mean ownership of the campus. Each respondent was asked to describe the ownership of their facilities, and then their written responses were analyzed. 
Information on ownership was received from 50 international branch campuses. The findings revealed five basic types of ownership patterns: (1) wholly owned by the home campus, (2) rented from a private party, (3) owned by the local government, (4) owned by a private partner, or (5) owned by an educational partner.

\section{WHOLLY OWNED}

The most common ownership arrangement (14 IBCs; 28\%) was for the home campus to wholly own the facilities of the IBC. This was somewhat surprising as the arrangement has the most financial risk associated with it. The development of a bricks and mortar campus can be quite costly; and should something go wrong (e.g., enrollments drop or the government changes the regulations), it may be difficult to recover the sunk costs if the campus operations are forced to close or be altered. However, it can also provide a level of stability as the home campus does not have to coordinate with a separate organization, in terms of the use or upkeep of the facilities. It also reduces the likelihood of a partner trying to leverage their ownership of campus to influence academic operations.

\section{GOVERNMENT PARTNERS}

After the wholly owned campus, the next most frequently cited arrangement (11 IBCs; $22 \%$ ) was for the local government to subsidize the cost of, and thereby own, the local campus. This model seems to be most common, where governments see IBCs as part of their economic growth strategy and want to provide incentives to attract specific institutions. Depending on the country, ownership can be by either local or national governments. In Qatar, the 
development of Education City, and the building of campus facilities, is handled by the Qatar Foundation, which is sponsored by the national government. Whereas, in Australia, Malaysia, and Europe, there are examples of local and state governments, investing in the facilities as a way to attract foreign institutions-which would help support local economic growth. In fact, at least two examples were found of local governments stepping up to build facilities for IBCs after the national government refused to support the development of a new public university in their region.

\section{Private InVestors}

A third ownership structure is found when a foreign academic institution (10 IBCs; 20\%) partners with a local private partner, usually an investment firm or property developer, to build the campus. In these cases, the private partner sometimes receives a stake in the revenues produced by the IBC, or they use the IBC as an "amenity" to help sell other property they own in the immediate vicinity.

\section{RENTING}

Nine $(18 \%)$ of the institutions rent their campus space. A couple of the rented facilities were located in Europe, but most of these institutions were located in Dubai Knowledge Village or Dubai International Academic City, which were designed primarily as a real estate development for foreign institutions to rent space. In this model, multiple institutions rent similar space in the same buildings or nearby buildings, creating a sort of shopping mall effect, whereby students have many academic options available to choose from. One of the more 
costly aspects of this endeavor is that the campuses had to pay for the furnishing and fixtures in addition to renting the space. In some instances, renting seems to be a transitional phase, as some institutions later build their own stand-alone campus buildings, moving out of the nearby rental facilities.

\section{ACADEMic PARTners}

Finally, in a very interesting arrangement, the IBC (6 IBCs; 12\%) is housed within the academic facilities of another campus. This partnership, of which examples were found in Asia and the Middle East, does not count as a dual or joint-degree program, as there is no academic partnership in place. Instead, the IBC uses the facilities to offer stand-alone academic programs. It is located in facilities owned by another college or university but operates separately from the other institution.

\section{CONCLUSION}

While the label "international branch campus" can imply that the ownership or condition of facilities is important in the model, most operating definitions only require that there be a physical presence in a foreign country. The research has revealed that IBCs actually come in many shapes and sizes, ranging from rented storefronts to government subsidized architectural wonders. These data reveal five models that universities use when seeking to establish an IBC's physical plant. It is important to note, however, that the use of these models will be limited, based on local regulations (e.g., some countries do not allow foreign ownership of facilities), as well as the ability to find a willing government, private, or academic partner to provide the space. Each arrangement comes with 
its own set of opportunities and obstacles. Wholly owned endeavors provide some stability and freedom from external interference but also pose a financial risk, should the enrollments not meet projections or government hospitality lapse. Partnering reduces the financial risks, but could lead to outside interference in academic affairs. While the models of facility ownership have been identified, more research is needed to understand their operational implications. 